\title{
The Yield Gap of Maize Under Intensive Cropping System in Central Java
}

\author{
DOI: $10.18196 /$ pt.v10i1.8789
}

\author{
Vina Eka Aristya*, Samijan \\ Assessment Institute for Agricultural Technology of Central Java, Ministry of Agriculture, \\ Jl. Soekarno - Hatta Km. 26 No. 10, Bergas, Semarang, Central Java, Indonesia 50552 \\ ${ }^{*}$ Corresponding author, email: vinaaristya@gmail.com
}

\begin{abstract}
The study aimed to estimate the level of the yield gaps of maize in major producing areas, point out the causes of yield gaps in farmers' maize fields, and identify opportunities to the existing yield gaps through management practices of maize production in Central Java. This is the strategy for closing the existing yield gaps to achieve food self-sufficiency in agricultural land. Methods to estimates the yield gaps should cover data sources on physical conditions (weather and soil), management practices, and smallholder shapes. The relevant methods for estimating actual yields (Ya), potential (Yp), and water-limited (Yw) were compared. The yield gaps of maize under intensive cropping systems in rainfed ecosystems resulted in significant differences in all cultivation situations. The lowland rainfed maize showed Ya, Yp, and Yw values of 5.57, 12.83, and 12.47 ton/ha, respectively. The major causes of the yield gaps include variety, land preparation, and water issues concerned with the limited water inputs.
\end{abstract}

Keywords: Central Java, Intensification, Maize, Yield Gap, Yield Potential

\section{ABSTRAK}

Penelitian ini bertujuan untuk mengetahui tingkat kesenjangan hasil komoditas jagung di daerah produksi utama, menunjukkan penyebab kesenjangan hasil di lahan jagung petani, dan mengidentifikasi peluang untuk menutup kesenjangan hasil yang ada melalui budidaya jagung di Jawa Tengah. Ini adalah salah satu strategi untuk menutup kesenjangan hasil yang ada untuk mencapai swasembada pangan di lahan pertanian. Metode untuk menilai kesenjangan hasil menggunakan sumber data terkait kondisi fisik (iklim dan tanah), budidaya tanaman, dan pertanaman petani. Kami membandingkan metode yang relevan untuk memperkirakan hasil pada kondisi aktual (Ya), potensial (Yp), dan keterbatasan air (Yw). Kesenjangan hasil komoditas jagung pada sistem penanaman intensif di ekosistem tadah hujan menyebabkan perbedaan yang sangat besar di semua kondisi budidaya. Hasil penelitian jagung di dataran rendah tadah hujan memiliki nilai Ya sebesar 5,57 ton/ha, Yp sebesar 12,83 ton/ha, dan Yw sebesar 12,47 ton/ha. Penyebab utama kesenjangan hasil jagung adalah varietas, persiapan lahan, dan keterbatasan petani dalam input air.

Kata Kunci: Hasil Potensial, Intensifikasi, Jagung, Jawa Tengah, Senjang Hasil

\section{INTRODUCTION}

The world population in 2050 is forecasted to countries (32\%) (FAOStat, 2021). Indonesia is the increase by $35 \%$, reaching over nine billion. Indo- 8 th largest maize-producing country in the world. nesia has a high population growth rate $(1.47 \%$ per However, it is uncertain to what extent can be year), and $75 \%$ of the population lives in Java (UN met considering the expected changes in diet and DESA, 2016). The needs for agricultural products, population (IFPRI, 2018).

especially maize, must be met by increasing global The maize production faces the challenges of the production (Laborte et al., 2012). The need for land, water, and world food systems in a climate maize farms is estimated to increase by $5 \%$, up to crisis. Future agriculture may produce more specific 227 million hectares, in 2030 (CGIAR-SO, 2021). agricultural products such as maize (Erenstein et The global maize area is 197 million ha with an al., 2021). Limited agricultural land and water average production of 1,137 million tons from 2017 resources have prompted major investments in to 2019. Maize is cultivated mostly in developing agricultural research and development to increase

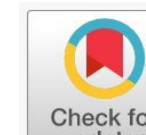


maize production and achieve food self-sufficiency in existing farmland. Lowder et al., (2021) also argue that maize farming has important implications for understanding the development challenges associated with the global agri-food systems and eliciting appropriate policy responses.

On the other hand, maize also faces reactions related to the yield gap. The analysis of the yield gap is meaningful to look how large the gap is between actual yields in farmer fields and potential yields of varieties and identify water-limited yield factors (Rattalino Edreira et al., 2017). Yield potential (Yp) is described as the yield of a well-adapted crop cultivar with non-limiting nutrients and water. Biotic stresses in this condition are effectively controlled (Van Wart et al., 2013). The yield potential of a cultivar in an environment adjusts with nutrient and water supplies. It involves effectively controlling weeds, pests, and diseases. Crop growth in optimal conditions is determined by temperature, solar radiation, and $\mathrm{CO}_{2}$ concentration. Management practices also impact crop cycle length of time and light interception, such as plant density, sowing date, and plant maturity (Van Ittersum et al., 2013).

Water-limited yield potential $(\mathrm{Yw})$ is related to Yp, but it also considers the influence of water supply quantity and distribution during the growing season, as well as the soil properties controlling the crop water balance (Van Ittersum et al., 2013). Yw is determined by distribution and water supply during the growing season. This case usually occurs in rainfed systems, in which water supply from inseason rainfall and stored soil water is not enough to meet crop water needs (Rattalino Edreira et al., 2017). Yp and Yw models rely on the climate, soil, and management data to assume the influence of genotype, environment, and management practices on crop growth and yield (Rotter et al., 2015).

The yield gap of maize cropping systems in Indonesia represents $56 \%$ and $58 \%$ of Yp and
Yw in irrigated and rainfed fields. The yield gap modeling is based on the local climate, soil, crop management, and farmers' maize yield data. At the national level, the average farmers' maize yield just ss $44 \%$ of $1344 \%$ of 13 represents. 6 ton/ha for the irrigated sites and $42 \%$ of 12.2 ton/ha in the rainfed fields. The yield gap is large enough due to uncertainties associated with land availability, irrigation expansion, the productivity of new land, and restrictions to modify crop sequences (Agus et al., 2019).

Closing the yield gap is a solution scheme to meet forthcoming maize demand. The potential yields are obtainable in spatial scale and specified cropping systems interest (Aramburu Merlos et al., 2015). Research on yield gaps in maize is still limited. The last studies about yield gaps in Central Java only revealed the value of rice commodities. The research has not explained any systematic effort to understand the causes and the value of yield gaps in maize (Boling et al., 2010).

Without a joint effort to measure maize yield gaps and understand their underlying explanatory factor, it will be difficult to orient and prioritize investments on interventions targets to close current yield gaps and increase food production in existing cropland areas. Self-sufficiency and opportunities for annual productivity can be achieved and identified, respectively, by closing the yield gaps. This study aimed to estimate the level of the yield gaps of maize in major producing areas, point out the causes of yield gaps in farmers' maize fields, and identify opportunities to close the existing yield gaps through management practices of maize in Central Java.

\section{MATERIALS AND METHODS}

This study was carried out in Grobogan, Central Java. The study sites represented irrigated lowland and rainfed upland ecosystems of maize (Zea mays). 
This study was conducted in two stages. The first stage was to estimate the level of the yield gaps of maize in major producing areas (April-November 2017). The second stage was to point out the causes of yield gaps in farmers' maize fields in Central Java and identify opportunities to close the existing yield gaps through management practices (AprilAugust 2018).

The range of maize yield and management in the farmers' fields was collected from on-farm. This major survey was performed to estimate the level of the yield gaps from the farmer's fields planted with maize over two crop seasons (2017 and 2018) in both wet and dry seasons. This study was carried out to assess variation in the selected farmers' fields. Yield gaps were investigated by figuring out data on maize grain yield, crop management practices, crop management, applied inputs, and production site adversities. Data were collected from multiple personal interviews with farmers in the course of over two agricultural seasons in the selected areas. Protocol based on Grassini et al., (2015) related to Global Yield Gap Atlas was used.

Supporting data sources in the form of climates (rainfall, temperature, humidity, and solar radiation) were collected during the last 18 years (2000-2017) from Semarang weather station, Indonesian Agency for Meteorology, Climatology, and Geophysics, and NASA POWER service. Data on the maize harvested area and average farmer yields were taken from 2010 and 2015 from Indonesian National Statistics. The soil data, description of annual cropping sequence, and crop system of study sites were available from the Ministry of Agriculture and local offices to support the research.

Low-yield and high-yield field classes were recognized based on their relevant presence in the lower and upper quartiles of the field yield distribution. Differences in each applied input and management practice between the low-yield and high-yield fields were assessed using t-tests. Association between categorical variables and field level was appraised using Chi-square $\left(x^{2}\right)$ tests (Stuart et al., 2016).

The second stage was a survey to identify the causes of the yield gaps. This technique was done using a stratified random sampling following the order of Province, Regency, Villages, Farmers, Fields, Years, and crop cycles. Five villages were selected according to the crop, while 20 farmers were selected for interview within each village. Hence, the total number of surveyed fields was 100 for the entire Central Java Province.

The interview method used was a face-to-face interview. The interviewer was provided with returned studies handed out by agronomists, agricultural extension educators, crop consultants, technicians, and researchers with guidelines to collect the data. The collected data also covered field location in the form of a face-to-face interview. The interviewer was provided with returned studies handed out by agronomists, agricultural extension educators, crop consultants, technicians, and researchers with guidelines to collect the data. The collected data also covered field location in the form of e pictures of the field taken in every corner of the farmers' fields for high accuracy location.

The survey design was determined based on the selection criteria for provinces, districts, villages, and farmers (Table 1). The study also aimed to identify opportunities to close the existing yield gaps through management practices.

The farmers are represented in the range of farmers in the local area. The farmers' maize fields data were selected not from the experimental sites, trial plots, and variety-testing plots. Farmer maize field is defined as a plot of land planted with maize managed with equal practices (e.g., planting/ transplanting date, fertilizer amount and timing, variety choice, plant density) and harvested at the same time. The collected data were avoided from 
Table 1. Design survey to identify the causes of yield gaps

\begin{tabular}{|c|c|c|}
\hline Stratified random sampling & Detail & Information \\
\hline Province & Central Java & Province was determined based on crop-specific harvested areas. \\
\hline Regency (1) & Grobogan & $\begin{array}{l}\text { Regency was selected based on: 1) large maize harvested area; 2) overlapping } \\
\text { with study area from the first stage of the project; 3) availability of meteorological } \\
\text { station; 4) logistically viable. }\end{array}$ \\
\hline Villages (5 per Regency) & $\begin{array}{l}\text { Depok, Kalongan, } \\
\text { Karanganyar, Ngraji, } \\
\text { Tambirejo }\end{array}$ & $\begin{array}{l}\text { Villages were selected based on the 1) representation of dominant crop sequence; } 2 \text { ) } \\
\text { distance between village at least 10-15 km to avoid overlapping. }\end{array}$ \\
\hline Farmers (20 per Village) & Total 100 Farmers & $\begin{array}{l}\text { Farmers were selected based on the 1) represented dominant soil types and crop } \\
\text { sequence; 2) represented range of socio-economic conditions; 3) reasonable } \\
\text { approachability to field visits; 4) farmers' interest in participating in the research } \\
\text { schemes }\end{array}$ \\
\hline Fields (1-3 per Farmer) & Total 100-300 Fields & $\begin{array}{l}\text { Fields selection reflected the most typical farm management practices and cropping } \\
\text { systems in the area }\end{array}$ \\
\hline Years (2) & 2017 and 2018 & $\begin{array}{l}\text { Yield and management practices data were collected from fields planted with maize } \\
\text { during } 2017 \text { and } 2018\end{array}$ \\
\hline $\begin{array}{l}\text { Crop Cycles } \\
\text { (2-3 per Year) }\end{array}$ & Rice-Rice-Maize & Data included the 2-3 crop cycles including maize within each year \\
\hline
\end{tabular}

lands planted with more than two varieties, or fields with portions planted at very different dates (more than a four-day difference). Outlier lands, fields not representing the range of management practices within the country, including organic farms, fields following typical crop sequences, or fields severely affected by unavoidable factors such as storms, rats, flooding, lack of water in irrigation schemes, suffered severe drought, and insect/disease damage. Maize grain yields (without cob) were reported at $15 \%$ moisture content.

The analysis for management practices implicating more than two distinguishable ways was classified into two categories. Variables showing significant effects on the yield, as expressed by the comparability between low-yield versus high-yield fields, were further investigated. Quantitative regression was used to derive limits for the relationship between delay in sowing date and farmer yield using the $\mathrm{R}$ program. Paired $\mathrm{t}$-tests were used for categorical variables (e.g., tillage), and mean yields were calculated for different management categories (e.g., fields with versus without tillage). ANOVA was conducted to assess the impact of yield in each regency, village, and farmer. Analysis of Pearson's correlation, based on the meteorological factors projected for each crop phase in the region (independent variables) and yield responses to different management factors (dependent variables), was performed to explore the biophysical basis for management and environment interactions (Rattalino Edreira et al., 2017).

\section{RESULTS AND DISCUSSION}

The Climates and Soils Orders of the Study Site

The study areas were selected to point out the causes of yield gaps in the farmers' maize fields in Grobogan, Central Java. This region has a major crop sequence of Rice-Rice-Maize (60\%). The production data were also collected to identify the largest crop area within Central Java Province. The fields that match the spatial locations of our study sites were selected for the project. Crop-specific harvested areas, lowland rainfed maize in Central Java, selected weather stations, and study areas around them were used to estimate the level of the yield gaps of maize in major producing areas.

Secondary data were used as the major references of weather data. The data on daily rainfall, minimum and maximum temperature, humidity, 
and solar radiation during 2000-2017 were collected and used to release weather data with quality control based on the relationship between adjacent weather stations and selected weather stations. Total annual rainfall was more than $2,730 \mathrm{~mm}$ in most locations. Tropical climate conditions in Grobogan, Central Java are good for growing complex crop systems in the same year on the same land. The agroecosystem at the study site is characterized by reliable distributions of rainfall patterns and strong weather (Figure 1 and 2).
During the last 18 years (2000-2017), the weather data from the target surveys are illustrative for the zone. The growing season of maize lasts from July to September. The minimum temperature of the study site in the last decade is around $21.2^{\circ} \mathrm{C}$, while the maximum temperature is about $32.9^{\circ} \mathrm{C}$. The average temperature at that location ranges . from 19.5 to $27.9{ }^{\circ} \mathrm{C}$. Total annual rainfall ranges from $715.8 \mathrm{~mm}$, and more than $2730 \mathrm{~mm}$ is in most parts of the area of lowland rainfed maize. The average humidity ranges from 52.1-79.7\%.

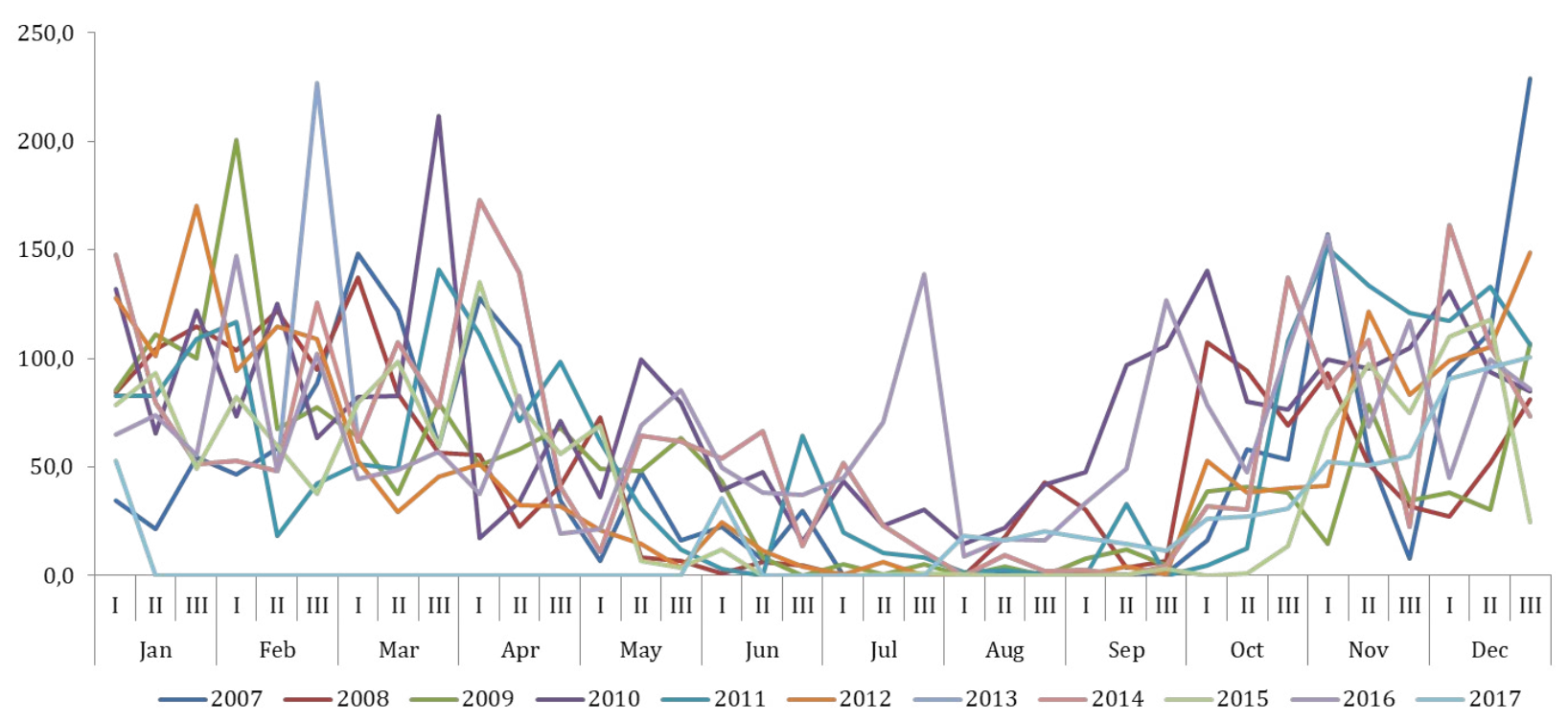

Figure 1. Trend rainfall in Grobogan, Central Java 2007-2017

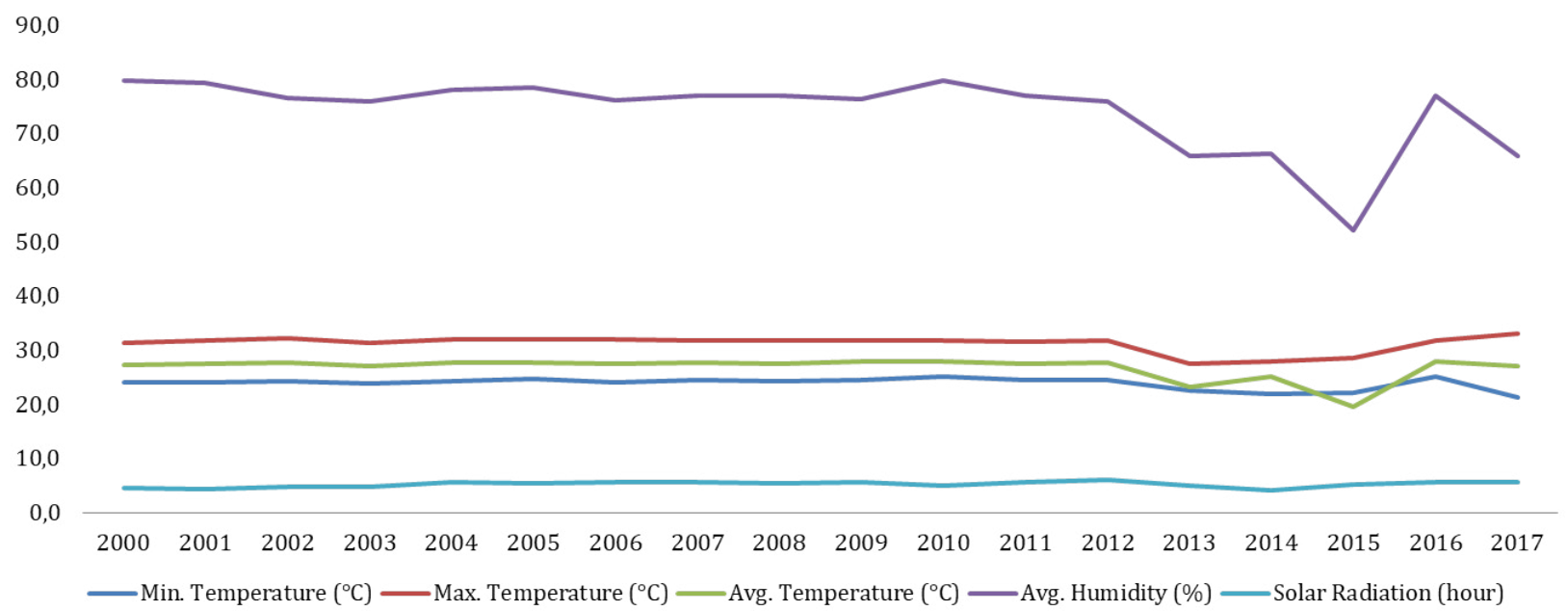

Figure 2. Temperature, humidity and solar radiation in Grobogan, Central Java 2000-2017 


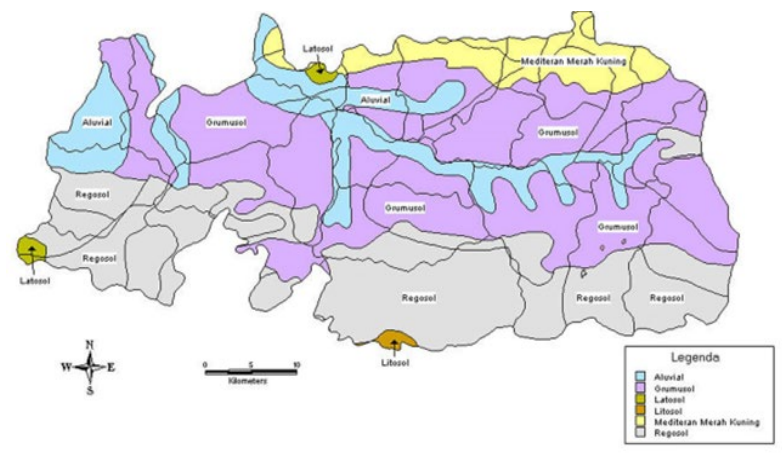

Figure 3. Dominant soil orders in Grobogan, Central Java

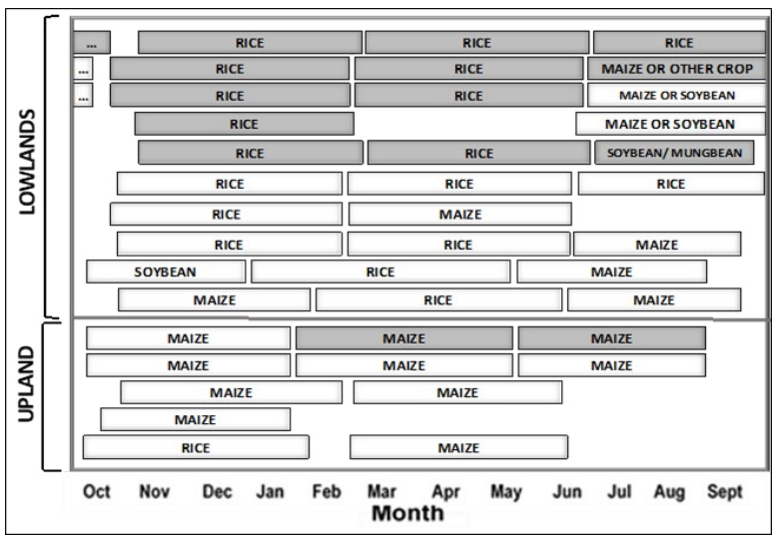

Figure 4. The complex crop systems in Central Java (October - September)

During the growing season, solar radiation in the study area varies from 4.2 to $5.0 \mathrm{MJ} / \mathrm{m}^{2} /$ day (Figure 3). The variability in temperature and rainfall conditions, excluding potential limiting factors, can give different estimates (Sheehy et al., 2006).

The medium-resolution soil maps were used to guide the selection of the villages in the location to ensure that their sites match the dominant soil maps in each region. Soil properties for the dominant agricultural soils in each buffer can be seen in Figure 3. Dominant agricultural soils in the lowlands area are Grumusol and Regosol. Grumusol is black soil, suitable for agriculture, and rich in calcium and magnesium. Meanwhile, Regosol is a very weakly developed mineral soil in unconsolidated materials. Soil map was used to identify 
Table 3. Description of crop system in Grobogan, Central Java

\begin{tabular}{lllllr}
\hline RWS name & Landscape & Water regime & Crop name & Growing season & Average grain yield (ton/ha) \\
\hline Semarang & Lowland & Irrigated & Rice & October-February & 7.15 \\
Semarang & Lowland & Irrigated & Rice & February-June & 5.31 \\
Semarang & Lowland & Manual watered and rainfed & Maize & June-September & 6.22 \\
\hline
\end{tabular}

Remarks: RWS=Reference Weather Stations

Table 4. Yield and water productivity levels of rainfed maize fields in Central Java

\begin{tabular}{clllll|ll}
\hline Harvest year & $Y a$ & $Y w$ & $Y p$ & WPP & WPA & Information & \\
\hline 2000 & - & 12.97 & 12.97 & 31.75 & - & Station & Semarang \\
2001 & - & 12.71 & 12.71 & 30.44 & - & Longitude & 110.511 \\
2002 & - & 12.58 & 12.61 & 30.39 & - & Latitude & -7.247 \\
2003 & - & 12.68 & 12.72 & 30.62 & - & Crop & Rainfed maize \\
2004 & - & 12.98 & 13.02 & 31.17 & - & Management & Lowland irrigated rice-rice rainfed maize \\
2005 & - & 12.85 & 12.92 & 30.66 & - & Crop cycle & 3 \\
2006 & - & 12.21 & 12.86 & 29.73 & - & Harvest year & $2000-2015$ \\
2007 & - & 12.65 & 12.85 & 31.06 & - & Sowing date & $05-J u n$ \\
2008 & - & 10.72 & 12.73 & 27.82 & - & Cultivar maturity & 1800 \\
2009 & - & 11.86 & 12.40 & 29.82 & - & Plant density & 80 \\
2010 & 4.62 & 12.65 & 12.70 & 30.84 & 11.26 & Used model & Hybrid Maize 2017 \\
2011 & 5.54 & 12.50 & 12.73 & 30.58 & 13.56 & Cropping intensity & 1.3158 \\
2012 & 5.71 & 13.02 & 13.02 & 31.12 & 13.66 & YW_CV temporal & 0.0525 \\
2013 & 5.83 & 11.30 & 13.17 & 28.64 & 14.77 & YP_CV temporal & 0.0151 \\
2014 & 5.95 & 12.98 & 13.05 & 31.23 & 14.32 & YA_CV temporal & 0.0874 \\
2015 & 5.78 & 12.87 & 12.87 & 30.86 & 13.86 & Climate zone & 9901 \\
\cline { 1 - 3 } Mean & 5.57 & 12.47 & 12.83 & 30.42 & 13.59 & Area in Climate zone (Ha) & 69105 \\
\hline
\end{tabular}

Remarks: Ya is the actual yield (kg/ha), Yp is the simulated yield potential $(\mathrm{kg} / \mathrm{ha}), \mathrm{Yw}$ is the simulated water-limited yield potential (kg/ha), WPP is water productivity potential $(\mathrm{kg} / \mathrm{ha} / \mathrm{mm})$, WPA is water productivity actual $(\mathrm{kg} / \mathrm{ha} / \mathrm{mm})$, and CV is the coefficient of variation. The unit of the yield levels $(Y a, Y p$, and $Y w)$ is tons per harvested hectare at standard moisture content. The unit of the water productivity levels (WPP and WPA) is kg per $\mathrm{mm}$ water per hectare.

Source: http://www.yieldgap.org/gygamaps/excel/GygaModelRunsIndonesia.xlsx

the dominant agricultural land, and the 1:50,000 scale map was used to compute the lowland area.

\section{Cropping Pattern of Study Site}

Annually, Central Java has a cropping system with an intensity that varies from one to three crops, for example, rice-rice-maize. The rainy season for most areas in Central Java starts from October and continues until March (Figure 4). The annual cropping sequence in Grobogan, Central Java is Rice-Rice-Maize with 25\% crop area. This study focused on the rainfed lowland maize. Dominant water regimes are annual watered and rainfed (dry Season). The estimated sowing is on May 20 to June 15 without transplanting, flowering date ranged from July 10 to August 5, and ripening stage started from August 30 to September 25. The dominant corn variety used was Bisi products. Farmers used plant densities of $(80 \times 40) \mathrm{cm}$ or $(40 \times 40) \mathrm{cm}$, with one or two seeds per clump (Table 2).

\section{The Level of the Yield Gaps of Maize}

The data on lowland areas in the regency level were obtained for rice and maize. The harvested area reported for each site has a function to estimate the average yield of the farmers based on regencies that overlap with the location of the buffers. The information obtained from official statistics, local extension agents, and agronomists were useful to assess grain yields and areas of maize 


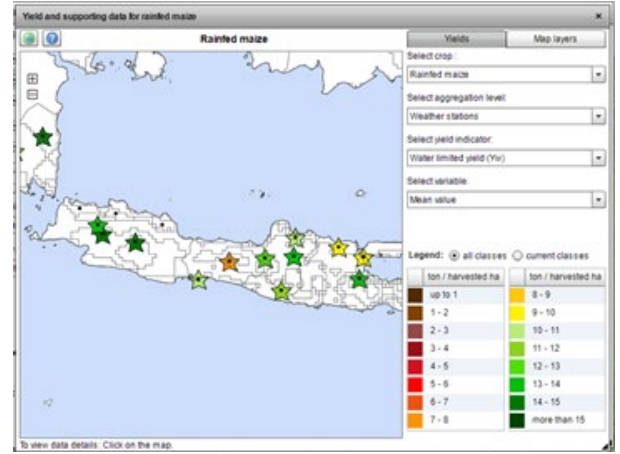

Water Limited Yield (Yw) 12-13 ton/harvested/ha

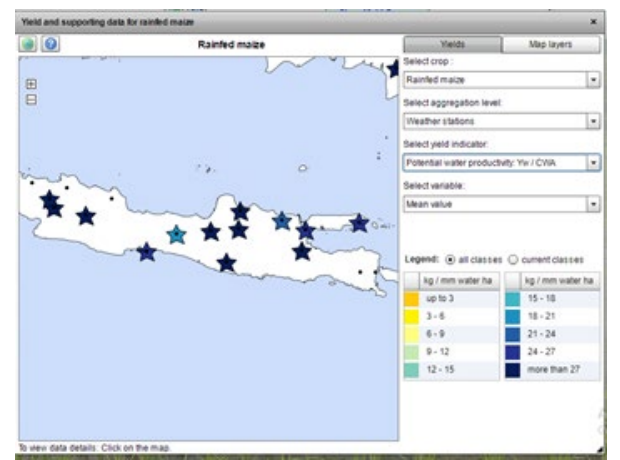

Potential Water Productivity $(\mathrm{Yw}) / \mathrm{CWA}$ more than $27 \mathrm{~kg} / \mathrm{mm}$ water ha

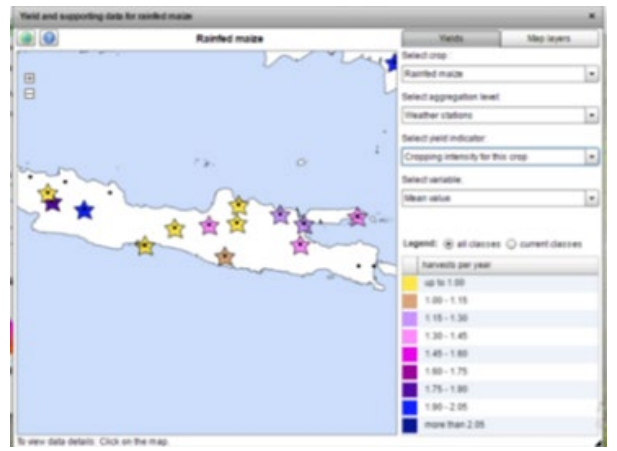

Cropping intensity for this crop 1.45-1.60 harvests per year

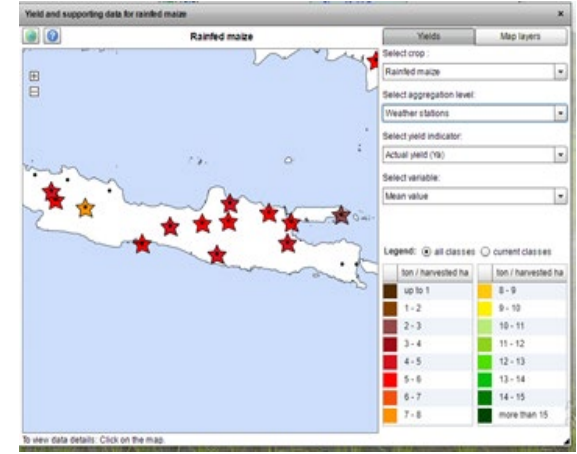

Actual Yield (Ya) 4-5 ton/harvested/ha

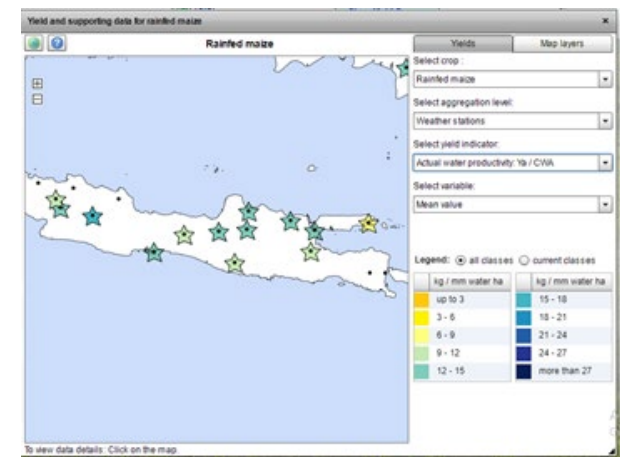

Actual Water Productivity (Ya)/CWA 15-16 kg/mm water ha

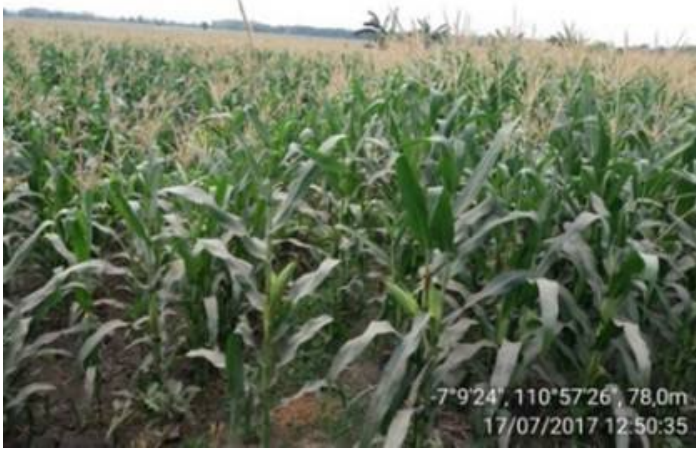

Maize on major producing areas

Figure 5. Yield and supporting data for rainfed maize, select aggregation level by the weather station. Source: http://www.yieldgap.org

for rainfed lowland.

with an average grain yield of $7.15,5.31$, and 6.22

In the study area, an overview of the context of ton/ha, respectively (Table 3).

the cropping system was obtained by taking 2010 The lowland rainfed maize fields at late stage of and 2015 data from RWS Semarang in the lowland harvest is prone to drought. There are high risks landscape. There are two types of water regimes, associated with landscapes, seasons, groundwater namely manual and rainfed irrigation. This region's depth across sites, and predisposing factors to maize most common cropping sequence is rice-rice-maize, yields. Both scenarios simulated the water-limited 


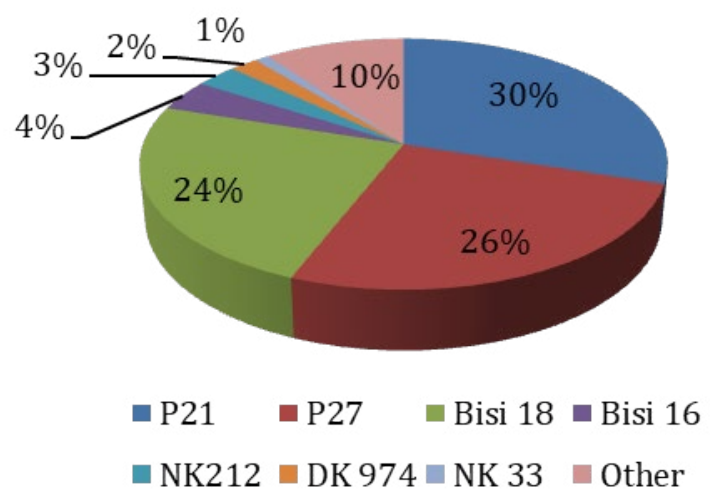

Figure 6. Maize' varieties used by farmers

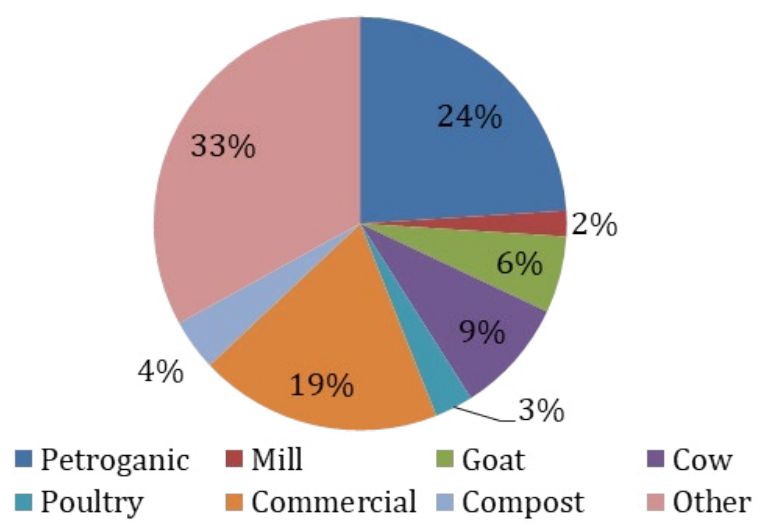

Figure 7. Manure sources applied by farmers

yield potential for lowland rainfed maize over the water-limited maize yields can be around $25 \%$. entire crop cycle. The first is a groundwater depth of $150 \mathrm{~cm}$ (deep), mainly describing drought-prone The Causes of Yield Gaps in Farmers' Maize Fields (deep) environments. The second is $10 \mathrm{~cm}$ (shal- The survey data obtained from the maize farmlow), which describes non-water limiting (shallow) ers were provided for management practices and environments. to inform the average maize yield for each of their

Rainfed maize fields in Central Java have Water fields in each year. The proposed management pracLimited Yield (Yw) of 12-13 ton/harvested/ha and tices for each RWS (Reference Weather Stations) Actual Yield (Ya) of 4-5 ton/harvested/ha, ranging include the dominant crop sequences, ecosystems, from 4 to 15 ton/harvested/ha across locations. water regime, total harvested area, maize manageThe current yield gap is 5.57 ton/ha $(60 \%$ of the ment (sowing and transplanting date, actual and potential). Crop Availability Water (CWA) is the optimal maize population density and spacing, amount of water supply during the growing sea- variety, and tillage system), applied inputs (nutrient son. The potential Water Productivity in Central fertilizer, lime, irrigation, manure, and pesticides), Java $(\mathrm{Yw}) / \mathrm{CWA}$ is more than $27 \mathrm{~kg} / \mathrm{mm}$ water ha and extent of abiotic and biotic stresses (flood, (30.42), and Actual Water Productivity (Ya)/CWA diseases, insect).

is $15-16 \mathrm{~kg} / \mathrm{mm}$ water ha. Major producing areas of maize have a cropping intensity of 1.45-1.60 harvests per year (Table 4 and Figure 5).

Lowland rainfed maize in Central Java is tech- areas (Figure 6).

nically not irrigated. During most of the growing The basic cross-correlation analysis of yield season, soil properties remain undersaturated gaps describes the causes of the yield gaps at the and regarded as non-water limited. Affholder et field scale. The indicators used include data crop al., (2013) argue that potential yields of primary management, soil constraints, and biotics. The food crops, especially maize, are under rainfed aftermath of various factors on the growth of maize in the tropics, which mostly does not show good and other results of crop population, nutrition, and results. Soil properties and rainfall influence the water limitations were evaluated separately. Table 5 groundwater balance for rainfed plant growth. The indicates there may be a large space for maize yield 
Table 5. The causes of yield gaps in farmers' maize fields

\begin{tabular}{ll:ll}
\hline Management practices & Farmer's method & Management practices & Farmer's method \\
\hline Air drying & after & NPK per ha & $279.38 \mathrm{~kg}$ \\
Establishment & direct & ZA per ha & $279.38 \mathrm{~kg}$ \\
Straight row method & no & SP36 per ha & $2.08 \mathrm{~kg}$ \\
Between row & $59.85 \mathrm{~cm}$ & Nrea per ha & $371.91 \mathrm{~kg}$ \\
Within row & $40.25 \mathrm{~cm}$ & Mate application & 225.59 \\
Plant per hill & 1.99 & Fungicide rate application & 9.24 \\
Seeding rate & 3.13 & Insecticide rate application & 0.38 \\
Establishment (month) & 6 & Wermones rate application & 0.83 \\
Establishment (day) & 12 & Weeding chemical application & 0.04 \\
Harvest (month) & 9 & & 0.44 \\
Field Area on google earth & 279.03 & $5.56 \mathrm{t}$ & 0.93 \\
Yield & &
\end{tabular}

Table 6. Famers management practices

\begin{tabular}{|c|c|c|}
\hline Information & Farmer's method & $\%$ \\
\hline \multirow[t]{3}{*}{ Land preparation } & no-tillage & 48 \\
\hline & minimum & 47 \\
\hline & full & 5 \\
\hline \multirow[t]{2}{*}{ Pumped water } & no & 65 \\
\hline & yes & 35 \\
\hline \multirow[t]{3}{*}{ Lime and manure } & none & 6 \\
\hline & manure & 93 \\
\hline & both & 1 \\
\hline \multirow[t]{2}{*}{ Straw management } & removed & 75 \\
\hline & left & 25 \\
\hline \multirow[t]{2}{*}{ Straw burning } & unburn & 46 \\
\hline & burned & 54 \\
\hline \multirow[t]{3}{*}{ Water issues } & none & 53 \\
\hline & deficit & 45 \\
\hline & excess & 2 \\
\hline
\end{tabular}

improvement due to the new actual yield chance. through increased $\mathrm{N}$ fertilizer. This application rate is expected up to $35 \%$ of current maize yields.

Management for improving soil fertility and ecological regulation requires the availability of organic matter and plant nutrients, especially phosphorus and nitrogen. Farmers' crop management applies several sources of organic manure from the surrounding area (Figure 7). The crop production will benefit from the addition of organic material and manure according to the recommended dosage. The combination of organic and chemical fertilizer can support a high grain yield of maize. This application is also useful for mitigating the negative impact on the environment (Zhang et al., 2021).

The results of interviews with farmers show that The farmers should shift from traditional to mod- land preparation is dominant with the no-tillage ern varieties suited to solve farming problems and method before planting. Most farmers apply waimprove market demand for yield grain. The maize tering management without a pump, and few use production dominated by smallholder farming pumped water (Table 6). The maize yield is highly systems shows management practices in Central sensitive to water source capacity. The lowest maize Java using N sources such as NPK and urea with yield was related to the lowest water source capacity. an $\mathrm{N}$ rate of application (Table 5). The study of Guidance is needed to identify and prioritize the Leitner et al., (2020) explains that increasing soil most appropriate strategies for optimizing yields fertility and closing the yield gap by $75 \%$ could be and water management (Araya et al., 2021). 
Table 6 showed that most farmers apply manure, remove the straws from the field, and burn the stalks after harvest. Half of the farmers don't have any problems in water issues, while the rest experiences water deficit and excess (Table 6). Study areas were used to identify the causes of yield gaps in Central Java, based on the cropping sequence Rice-Rice-Maize (60\%). The estimated planting seed was from May 20 up to June 15.

For instance, Affholder et al., (2013) stated that cropping management with low density on fields had a greater negative effect on the maize yield. The relatively higher global radiation could be profitable at an early stage of maize growth. Maize cultivation is more favorable in the competition for nutrition, water, and light at the end of the season.

\section{CONCLUSIONS}

The tropical climate of Central Java is feasible to grow complex crop systems on the same plot of land in the same year. The yield gaps of maize under intensive cropping systems in rainfed ecosystems cause variation between cultivation situations. The rainfed maize field in the lowland area in Central Java showed a Potential Yi variation between cultivation situations. The rainfed maize field in the lowland area in Central Java showed a Potential Yie variation between cultivation situations. The rainfed maize field in the lowland area in Central Java showed a Potential Yield variation between cultivation situations. The rainfed maize field in the lowland area in Central Java showed a Potential Yield variation between cultivation situations. The rainfed maize field in the lowland area in Central Java showed a Potential Yield (Yp) of 12.83, ranging from 4 to 15 ton/ha. Meanwhile, the Actual Yield (Ya) was 5.57, reaching 4-5 ton/ha per harvest, and the Water Limited Yield (Yw) was 12.47, reaching 12-13 tons/ha. The current yield gaps in major producing areas are re 5.57 ton/ha $(60 \%$ of the potential). Maize production in major areas has a cropping intensity of 1.45-1.60 per year. The causes of the yield gap from farmers are on-farm data that well describe the range of maize yield and management across farmers' fields. The major causes of yield gaps in farmers' maize fields are variety, land preparation, and water issues concerned with the incapacity of farmers to water inputs. Understanding the mechanism leading to the yield gap can accelerate the reach of self-sufficiency and increase opportunities for annual maize productivity to close the existing yield gaps through management practices of maize.

\section{ACKNOWLEDGEMENTS}

The authors are grateful for the financial support through Global Yield Gap Atlas Indonesia Project from Indonesian Agency for Agricultural Research and Development. Gratitude is expressed to Prof. Patricio Grassini (University of NebraskaLincoln, USA) and Prof. Fahmuddin Agus (Center for Agricultural Land Resources Research and Development) for insightful comments on this research. The authors also thank Yuni Kamal and Warsito (Assessment Institute for Agricultural Technology of Central Java) and Agricultural Extension from Grobogan Regency for excellent support in the fields.

\section{REFERENCES}

Affholder, F., Poeydebat, C., Corbeels, M., Scopel, E. \& Tittonell, P. (2013) The yield gap of major food crops in family agriculture in the tropics: Assessment and analysis through field surveys and modelling. Field Crops Res., 143, 106-118, http://dx.doi. org/10.1016/i.fcr.2012.10.021.

Agus, F., Andrade, J.F., Rattalino Edreira, J.I., Deng, N.Y., Purwantomo, D.K.G., Agustiani, N, Aristya, V.E., Batubara, S.F., Herniwati, Hosang, E.Y., Krisnadi, L.Y., Makka, A., Samijan, Cenacchi, N., Wiebe, K. \& Grassini, P. (2019) Yield gaps in intensive rice-maize cropping sequences in the humid tropics of Indonesia. Field Crops Res., 237, 12-22, https://doi.org/10.1016/j.fcr.2019.04.006. Aramburu Merlos, F., Monzon, J.P., Mercau, J.L., Taboada, M., Andrade, 
F.H., Hall, A.J., Jobbagy, E., Cassman, K.G. \& Grassini, P. (2015) Potential for crop production increase in Argentina through closure of existing yield gaps. Field Crops Res. 184, 145-154, https://doi.org/10.1016/j.fcr.2015.10.001.

Araya, A., Gowda, P.H., Rouhi Rad, M., Ariyaratne, C.B., Ciampitti, I.A., Rice, C.W. \& Prasad, P.V.V. (2021) Evaluating optimal irrigation for potential yield and economic performance of major crops in southwestern Kansas. Agric. Water Manag, 244, 106536, https://doi.org/10.1016/j.agwat.2020.106536.

Boling, A.A., Tuong, T.P., van Keulen, H., Bouman, B.A.M., Suganda, H. \& Spiertz, J.H.J. (2010) Yield gap of rainfed rice in farmers' fields in Central Java Indonesia. Agric. Syst., 103, 307-315, doi: 10.1016/j.agsy.2010.02.003.

CGIAR-SO (2021) CGIAR 2030 Research and Innovation Strategy: Transforming Food, Land, and Water Systems in a Climate Crisis. CGIAR System Organization, Montpellier, France. https://hdl. handle.net/10568/110918.

Erenstein, 0., Chamberlin, J. \& Sonder K. (2021) Estimating the global number and distribution of maize and wheat farms. Glob. Food Sec., 30, 100558, https://doi.org/10.1016/j.gfs.2021.100558.

FAOStat (2021) FAO Stat. FAO, Rome. Available at: http://www.fao. org/faostat. Last accessed 25.8.2021.

Grassini, P., Torrion, J.A., Yang, H.S., Rees, J., Andersen, D., Cassman, K.G. \& Specht, J.E. (2015) Soybean yield gaps and water productivity in the western U.S. Corn Belt. Field Crops Res., 179, 150-163, http://dx.doi.org/10.1016/j.fcr.2015.04.015.

IFPRI (International Food Policy Research Institute) (2018) 2018 Global Food Policy Report. International Food Policy Research Institute, Washington, DC. https://doi. org/10.2499/9780896292970.

Laborte, A.G., de Bie, C.A.J.M., Smaling, E.M.A., Moya, P.F., Boling, A.A. \& Van Ittersum, M.K. (2012). Rice yields and yield gaps in Southeast Asia: past trends and future outlook. Eur. J. Agron., 36, 43(1), 9-20, doi: 10.1016/j.eja.2011.08.005.

Leitner, S., Pelster, D.E., Werner, C., Merbold, L., Baggs, E.M., Mapanda, F. \& Butterbach-Bahl, K. (2020) Closing maize yield gaps in sub-Saharan Africa will boost soil N2O emissions. Curr. Opin. Environ. Sustain, 47, 95-105, https://doi.org/10.1016/j. cosust.2020.08.018

Lowder, S.K., S'anchez, M.V. \& Bertini, R. (2021) Which farms feed the world and has farmland become more concentrated? World Dev., 142, 105455, https://doi.org/10.1016/j.worlddev.2021.105455

Rattalino Edreira, J.l., Mourtzinis, S., Conley, S.P., Roth, A.S., Ciampittic, I.A., Lichtd, M.A., Kandele, H., Kyverygaf, P.M., Lindseyg, L.E., Muellerh, D.E., Naevei, S.L., Nafzigerj, E., Spechta, J.E., Stanleye, J., Statonk, M.J. \& Grassini, P. (2017) Assessing causes of yield gaps in agricultural areas with diversity in climate and soils. Agric. For. Meteorol., 247, 170-180, http://dx.doi.org/10.1016/j. agrformet.2017.07.010

Rotter, R.P., Tao, F., Hohn, J.G. \& Palosuo, T. (2015) Use of crop simulation modelling to aid ideotype design of future cereal cultivars. J. Exp. Bot., 66, 3463-3476. doi: 10.1093/jxb/erv098.

Sheehy, J.E., Mitchell, P.L. \& Ferrer, A.B. (2006) Decline in rice grain yields with temperature: Models and correlations can give different estimates. Field Crops Res., 98, 2-3, 151-156, https:// doi.org/10.1016/j.fcr.2006.01.001.

Stuart, A.M., Pame, A.R.P, Silva, J.V., Dikitanan, R.C., Rutsaert, P., Mala- bayabas, A.J.B., Lampayan, R.M., Radanielson, A.M. \& Singleton, G.R. (2016) Yield gaps in rice-based farming systems: Insights from local studies and prospects for future analysis. Field Crops Res., 194, 43-56, http://dx.doi.org/10.1016/j.fcr.2016.04.039.

UN DESA (2016) World population prospects 2016. Available at: https://esa.un.org/unpd/wpp/Graphs/DemographicProfiles/ Last accessed 20.11.2019.

Van Ittersum, M. K., Cassman, K. G., Grassini, P., Wolf, J., Tittonell, P. \& Hochman, Z. (2013). Yield gap analysis with local to global relevance - a review. Field Crops Res., 143, 4-17, http://dx.doi. org/10.1016/j.fcr.2012.09.009.

Van Wart, J., Grassini, P. \& Cassman, K.G. (2013) Impact of derived global weatherdata on simulated crop yields. Glob. Change Biol., 19, 3822-3834, doi: 10.1111/gcb.12302.

Zhang, Y., Yan, J. Rong, X., Han, Y., Yang, Z., Hou, K., Zhao, H. \& Hu, W. (2021) Responses of maize yield, nitrogen and phosphorus runoff losses and soil properties to biochar and organic fertilizer application in a light-loamy fluvo-aquic soil. Agric. Ecosyst. Environ., 314, 107433, https://doi.org/10.1016/j. agee.2021.107433. 